\title{
Study on the Factoring Model of Account Receivable Management for Chinese Enterprises
}

\author{
J.L. LIU \\ International College of Xiamen University, Xiamen, Fujian, China
}

\begin{abstract}
In abroad, factoring is well developed and widely applied on managing the account receivable. Its validities are verified on the aspects of transferring financial risk, bringing down press of account receivable and improving finance structure. Yet in China, factoring is at a fast developing stage but still with a few problems. With the imperfect credit system, enterprises in China aggregate large amount of money on the account receivable. As a new comprehensive financial service, factoring makes apparent effects on respond to account receivable risks but also the acceleration of funds operation. This essay intends to explore the problems of factoring existed in China and provide some suggestions to expand factoring business.
\end{abstract}

KEYWORD: Account receivable management, factoring, risk prevention

\section{INTRODUCTION}

\subsection{Background}

Factoring is a set of comprehensive financial services of trade financing, bad debts secure. Factoring of account receivable means that the enterprises transfer the unmatured account receivables, which are made by the sales on credit, to the commercial banks when the specified conditions are satisfied. Then the commercial banks provide the fund for enterprises and take charge of management and collection of account receivable, bad debts secure and so on. By this way, enterprises can acquire the cash payment in a short time while the cost of financing is also lower than loans at large. Factoring keeps enterprises out of trouble of account receivable management and as a result, the enterprises can collect the receivables, accelerate the capital turnover and finally improve their competitiveness. For these commercial banks which provide the Factoring businesses, Factoring not only circulates necessary funds but also reduces the risk of receivables collections. Meanwhile, because the account receivable is sold at a discount to the commercial banks, the factor can also get the profits, which is in favor of resolving the potential financial risks. Therefore, Factoring is a win-win form of dealing with enterprises' account receivable.

\section{PRESENT SITUATION ANALYSIS OF ACCOUNT RECEIVABLE FACTORING FOR CHINESE ENTERPRISES}

\subsection{Starting late, developing fast, but comparatively few entities provide the factoring}

In 1992, Bank of China was the first financial institution that introduced the Factoring to domestic market and joined the Factors Chain International (FCI) one year later. Although subsequently the Bank of Communications also became one formal member of FCI, Factoring in China is slow developed until 2010. The event of Ericsson (Nanjing)'s betrayal stimulate the development of Factoring to a certain degree. Afterwards, most commercial banks pay more attention on the factoring's popularize and expending. Consequently, the volume of Factoring businesses in China increases year by year which help China be one area of the fastest developing factoring in the world. From the table 1, we can see that the volume of factoring businesses in China has increased from $€ 55$ billion in 2008 to $€ 378.1$ billion in 2013.

Table 1 The volume of factoring businesses in China from 2008 to 2013 Unit: billion Euro

\begin{tabular}{|c|c|c|c|c|c|}
\hline 2008 & 2009 & 2010 & 2011 & 2012 & 2013 \\
\hline 55.0 & 67.3 & 154.5 & 274.9 & 343.8 & 378.1 \\
\hline
\end{tabular}

In spite of the apparent ascend of the volume of factoring businesses in China, the share of market of 
the volume in our country is still very small, compared with countries and areas that have mature factoring businesses.

Table 2 the Total volumes of Factoring Comparison of other countries (2008-2013) Unit: billion Euros

\begin{tabular}{|l|l|l|l|l|l|l|}
\hline & 2008 & 2009 & 2010 & 2011 & 2012 & 2013 \\
\hline United States & 100.0 & 88.5 & 95.0 & 105.0 & 77.5 & 83.7 \\
\hline $\begin{array}{l}\text { United } \\
\text { Kingdom }\end{array}$ & 188.0 & 195.6 & 226.2 & 268.1 & 291.2 & 308.1 \\
\hline Japan & 106.5 & 83.7 & 98.5 & 111.2 & 97.2 & 77.3 \\
\hline China & 55.0 & 67.3 & 154.5 & 274.9 & 343.8 & 378.1 \\
\hline $\begin{array}{l}\text { TOTAL } \\
\text { WORLD }\end{array}$ & $1,324.7$ & $1,283.6$ & $1,648.4$ & $2,015.0$ & $2,132.2$ & $2,230.4$ \\
\hline
\end{tabular}

Source: $h t t p: / / w w w . f c i . n l$

The Table 2 indicates the comparison of some countries. From the table above, the United Kingdom used to have the largest volume of factoring before 2010, which is 226.2 billion and the world's total amount is around 1,648.4 billion Euros. This amount for China is 154.5 billion Euros which is $68.30 \%$ of United Kingdom and $9.37 \%$ of the global. However, things are changed then. By 2013. China has become top one in the volume of factoring businesses. By these data above, we can see that China's factoring is developed fast in recent years. It approves that either from the theoretical perspective or the real situations, factoring in China owns numerous advantages.

However, things will not going well at every aspects. In FCI, there are 27 Full Members in China including only two who are not commercial banks (Fortune International Factoring Co. Ltd and Hong Tai International Factoring (Tianjin) Co. Ltd).(Fci.nl, 2015) One risk for such situation is that, for those commercial banks, factoring is only one of their intermediary business and these banks do not set up a separate department to do business of factoring. Instead, it is concurrently engaged in by other related functional departments.

The major risk that Factor must bear in factoring business is the credit risk of the debtor. Factors can undertake some of it as well as transfer some to insurance companies. Whereas for Without Recourse factoring, banks can not recover the money form the sellers and when debtor defaults, banks will sustain $100 \%$ bad debt guarantee losses. In abroad, Factors usually assure on the insurance companies for proportional factoring business turnover. In other words, once the bad debt within bank approved line of credit occurs, it will be compensated for proportional by insurance company. Cooperating with insurance companies, Factors lower the operating risks they take. Nevertheless, the system of China's financial industry is divided operation and multi-supervision. As a result of that, at present, there is neither commercial insurance company nor Guarantee Company willing to do further assurance for Without Recourse Factoring, except China Export \& Credit Insurance Corporation who can only provide policy Export \& Credit Insurance. At this moment, commercial banks have not system of access standards and cooperation experiences with insurance banks. So they only have to bear the sole credit risks possibly took place.

\subsection{Serious lack of experienced professional staff}

Internationally, it is the FCI draws up "Code of International Factoring Customs". This rule is used for directing the factoring for countries, but it yet cannot directly supervise and direct the concrete implementation in China. In additional, members of our country who have joined FCI are lack of acquaintance of international agreement, operations experiences and international communications. All these disadvantages make kinds of problems occur in practical operations of account receivable factoring and hardly be solved.

Factoring is a comprehensive financial service provided to enterprises and functional in fields of international settlement, financing, credit guarantees, cash flow management, etc. It is also involved in business scopes of international trade, bank, law, IT and so on. Therefore, staffs undertaking the factoring are required to own the abilities to fluently used English and computer operation. Besides those, rich knowledge of international finance and laws is also needed. And the moment China's employed persons of factoring are not professional trained in majority for factoring operating and short of the practical operations, which has a strong impact on factoring's promotion speed and applied range in China. On the other hand, because of the unprevailing situation of factoring, corresponding cultivation mechanism for this kind of professional staff is still disappearance in China. The fact is that in the colleges and universities professional learning of finance or trade, factoring is involved but only glanced off. Introductions of practical operations are not in detail. All in all, serious lack of experienced professional staff contributes to unsatisfied services of factoring in China and influences the fast-speed development of factoring in consequent.

\subsection{A blank existence in legislation about factoring in China}

Up to now, the complete legal system of factoring has not been formed at present in our country. Although we have, in practical, accepted international standard operating disciplines such as International Factoring Management Code by FCI, International Factoring Service Convention, Arbitration Rules published internationally, these 
legal norms still can not directly guidance and monitor the specific contents of factoring in China. The State Administration of Foreign Exchange (SAFE) do not issue Relevant Questions Concerning the Measures for the Administration of the Collection Verification and Writing-off of Export Proceeds in Foreign Exchange for Export Factoring until July, 2003, which helps to regulate cancel despite verification of export factoring. Factoring provided by Chinese commercial banks, is filling in People's Bank of China as intermediary business and the central bank do not set rules of factoring's operation mode either. That is to say, People's Bank of China gives policy allowance to commercial banks to do factoring business following their own ways. Due to these, the operation of factoring are always in the awkward which have no law to depend on or even if has laws but hard to follow.

\section{COUNTERMEASURE ANALYSIS OF ACCOUNT RECEIVABLE FACTORING IN CHINA}

Before 2012, factoring develops extremely slower in China. However, with the increasing needs for factoring and supports from the government, Chinese factoring market enter an new era.

\subsection{Relax restrictions of establishing independent firms of factoring and strengthen cooperation of banks and insurance companies, domestically and overseas}

In past a few years, only commercial banks can do factoring businesses, which means that financing standards related to factoring have to based on requirements of issuing a loan by commercial banks. The advantage of factoring disappears in total. For the reason that factoring can not be separated from commercial banks immediately, they are suggested to setting up a specialized department, paying more attention on professional training. It is also advised that, banks should independently operate the factoring business according to the independent rules. Meanwhile, the supervision and regulation department ought to loosen the restrictions of factoring as soon as possible and allow the independent factoring company being built up. Only by doing these can factoring separated from banking business and be done by independent factoring companies.

Besides, we should strengthen cooperation with foreign invested banks and factors, introduce advanced operation technologies and professional practical experiences. Then based on regulating the operation, we have to prevent risks actively and effectively. At the same time, taking advantages of large amount of branches of commercial banks and insurance companies, we can develop the factoring market and introduce benefit actuation mechanism into our country's factoring by coordinating factoring businesses and policies that encourage enterprises' development.

\subsection{Cultivate high quality talents of factoring actively and increase efficiency of factoring}

The characteristics of factoring let the personnel who are engaged in factoring have to own high level of English and factoring knowledge, good ability to master trading knowledge and comprehensively financial analysis. Enough understanding of laws, treaties, and regulations are also required to make up a feasible way of credit extension and lower down the risks of themselves.

In China, personnel engaged in factoring are in short. Banks and companies can cooperate with financial institutions, colleges, and universities to co-culture the professional personnel. On behalf of persons who are now occupied in factoring in China, banks or companies can invite some experts from foreign factoring companies who have good relations with to introduce the foreign factoring practical experiences, the latest developments and ways of risk preventions. factoring employees from internal institutions can study and discuss, exchange experiences of doing factoring business in China and deliberate the Code of International factoring Customs as well. On the other side, bans and enterprises can also chose employees to study in abroad. They can enter the one-year correspondence course of training about factoring which is held by Factors Chain International (FCI) in order to get the latest issues and trends of international factoring developments and improve the ability of operation. Finally, we can bring on board to expect the improvement of comprehensive ability and professional skills of Chinese factoring personnel.

\subsection{Improving the laws and regulations of international factoring.}

In June 2012, the Commerce Department of China has published the 'announcement about commercial factoring pilot'. And in the same year, Shanghai and Tianjin introduces measures about commercial factoring pilot. This is the main reason of rapid development of factoring after 2012. However, the blank of legal regulation needs to be filled with more actions.

Learning mature management experience from abroad is useful for improving the laws and regulations of factoring. China should promulgate management rules, detailed regulations and operation instructions for doing factoring in practical as fast as possible, as well as reinforce on-site supervisions and risk prevention. Firstly, the current 
laws and regulations such as Contracts Law, Corporation Law, Bank Act, Security Law, and Bankruptcy Law and so on, should be revised and improved for their parts linked with factoring. On the other hand, Chinese financial regulator is advised to make factoring management rules and operation instructions which are fit for our own national conditions according to Convention on International Factoring and Code of International Factoring Customs.

Therefore, People's Bank of China should speed up to make related policies and the Legislature should reinforce the related legislative works. Then the domestic factoring industry has laws to abide by, has rules to follow and it well development can be guaranteed. Each commercial bank should make great effort to strengthen self-discipline within doing factoring businesses. Meanwhile, they can be horizontal alliance for the purpose of reduce differences occurred in operating this business. Experiences of both domestic and abroad help the uniformed operation mode be formed. This can not only prevent financial risks, but provide a few beneficial basis for legislation and references for judicial practice.

\section{CONCLUSION}

Properly using factoring has positive impacts for both enterprises and banks. From the side of enterprises, they can reduce account receivables, improve financial statements, and decrease bad debts provision for prior year and increase profits accordingly, though they have to pay some service fees for these. Besides, they are able to transfer forward account receivables to current cash inflows in order to alleviate financial strain. Thus, domestic companies must change their old thinking. For the long-time and hard-collected account receivables, timely disposal is better than doing nothing because the account receivable does not equal to assets can be really collected when it is recorded as historical costs. From the side of banks, along with the fact that rooms for deposit and lending business is smaller and smaller, one of commercial banks' intermediary services, factoring has higher profit compared with traditional lending business. Moreover, as the specified financial institutions, banks own their obvious experiences and advantages in prospects of asset management and loan recovery.

Capital, as a scarce resource in the society, is the key factor of enterprise's development forever. And whether one can efficiently use the limited capital is very important as well. Fro a long time, China's enterprises' account receivables have huge amount and are on credit since long time ago. Account receivable has become a barrier of capital turnover, market development and refunding. As an emerging business, the factoring provides a new way for account receivable's dealing.

\section{REFERENCES}

[1] Chen, Yongbo 2007. Study on company's management of account receivable credit. Science and Technology Consulting Herald 21: 92-92.

[2] Commerce Department of China, 2014. Report on the Development of Chinese Commercial Factoring Industry 2013.

[3] FCI, 2014 Factors Chain International Annual Review 2014. Amsterdam.

[4] Fci.nl 2015. Factors Chain - Asia. [online] Available at: http://www.fci.nl/fci-members/select-a-member/asia?c $=\mathrm{CN}$ [Accessed 11 Feb. 2015].

[5] Feng, Yunlin 2007. Management of Account Receivable. Shanxi Finance and Tax 4: 32-33.

[6] Investopedia, 2003. Factor Definition | Investopedia. [online] Available at: http://www.investopedia.com/terms/f/factor.asp [Accessed 7 Feb. 2015].

[7] Wang, Jie \& Qiao, Xianglan 2013. Current situation and countermeasures for international factoring in China. Commercial Times 3.

[8] Tian, Hai 2012 Study on dilemma and legal improvement of international factoring for middle and small-sized enterprises in China. China Business and Market 7.

[9] Zhou, Huanyu 2009. Analysis of developing account receivalbe's factoring business for commercial banks. $\mathrm{CO}$ Operative Economy \& Science August 2009. 